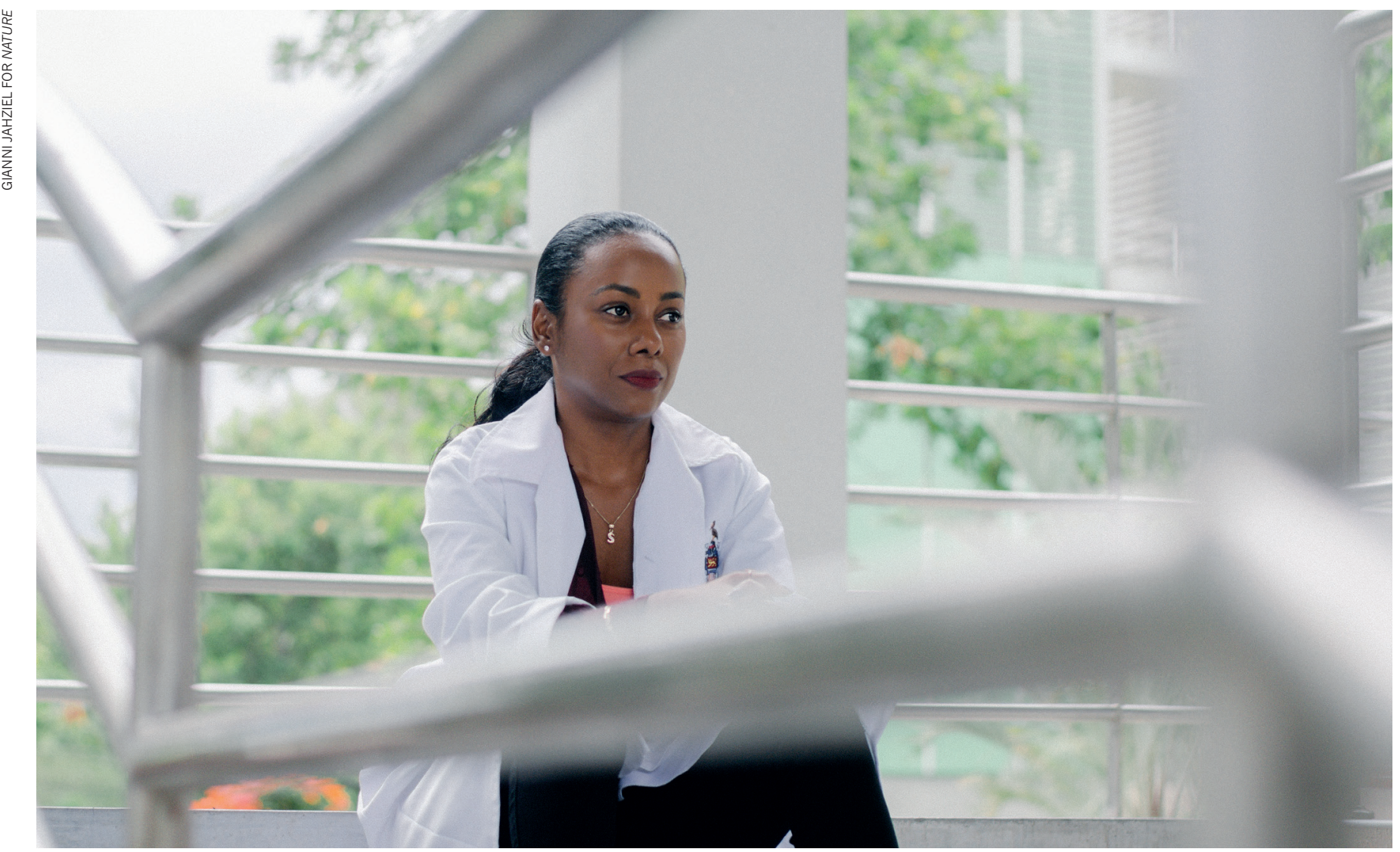

Simone Badal McCreath is attempting to establish a Caribbean cancer cell line.

\title{
Biotechnologists breaking fresh ground
}

\section{Nature meets five scientists working in non-Western nations who are making the most of local resources.}

W estern nations claim much of the glory when it comes to biotechnology, but scientists elsewhere are making substantial progress.

SIMONE BADAL MCCREATH Jamaica's natural biotech wealth

Research fellow and lecturer at the University of the West Indies in Mona, Jamaica.

Jamaica is blessed with sun, sea, sand and a wealth of natural resources - it ranks fifth among the world's islands in terms of endemic species.

"That means these products, these plants are nowhere else," says Simone Badal McCreath, a research fellow in the Department of Basic Medical Sciences at the University of the West Indies in Mona, Jamaica. "Which means we are sitting on novel compounds that, once assessed against a wide array of biological activities, could help to make products that can treat Huntington's disease or neurological disorders, for example."

Badal McCreath's interest in the potential of naturally derived compounds goes back to her $\mathrm{PhD}$, when she was working on their anticancer properties. "Natural products display a wide array of biological activities, and I suppose you could say that was how my interest or love for biotechnology developed," she says. During her research on natural sources of anticancer compounds, she realized that most cancer cell lines used to study these compounds were from white people.

"It got me thinking, would these compounds be just as effective against cell lines of African origin?" she says. "So I went and I searched for African cell lines, and I recognized that there were no cell lines that represented the Caribbean."

It spurred her to begin establishing the first Caribbean cancer cell lines. She has already started on a Caribbean prostate-cancer cell line and plans to develop more. But it's high-risk research: there is barely a $10 \%$ success rate in establishing these cell lines, which requires collecting and cultivating cells from tumours. 
- In March, the Jamaican government announced an injection of 200 million Jamaican dollars (US\$1.5 million) into scientific research, including biotechnology, in its 2019-20 budget, but there are few other opportunities for grants and funding in the country. In such a pinched environment, Badal McCreath advises aspiring biotechnologists to take advantage of their connections. "Create a strategy with the help of those who've succeeded at the field," she says.

Badal McCreath is optimistic for the future of her research, and has clear goals of not only establishing a library of Caribbean cancer cell lines, but also establishing a cancer-research facility in Jamaica. "It gives me much joy and passion and humility to know that I can be a part of making history and be a part of making an impact on somebody else's life," she says.

\section{SUSHILAMAHARJAN Bringing science back home}

\section{Research director at the Research Institute for Bioscience and Biotechnology in Kathmandu, Nepal.}

When Sushila Maharjan undertook her undergraduate studies in science in Nepal in the early 2000s, there were no research institutes for basic science in the country. She decided to change that.

First, she obtained a $\mathrm{PhD}$ in biochemistry, from Sun Moon University in Assan, South Korea, in 2011, on research into genetically engineering bacteria to produce more potent antibiotics and anticancer drugs. She also gained industry experience during a postdoctoral research fellowship in a biomedical engineering lab at Seoul National University, where she studied drug- and vaccine-delivery mechanisms.

"My long-term aim was to establish a research institute in Nepal to promote science and technology in my own country," says Maharjan. During her postdoctoral work in Seoul,

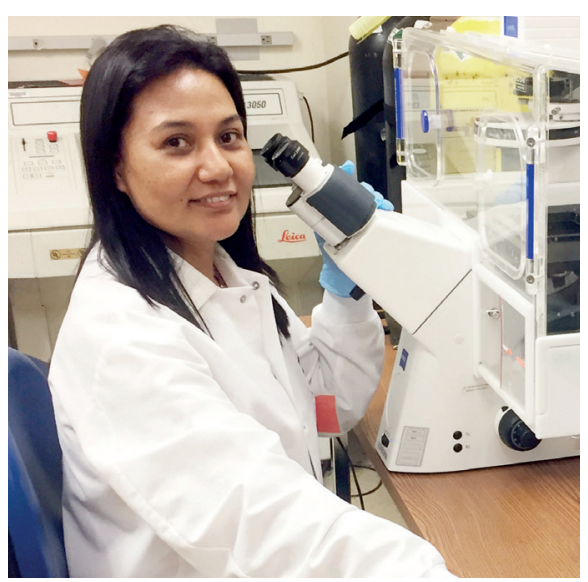

Sushila Maharjan.

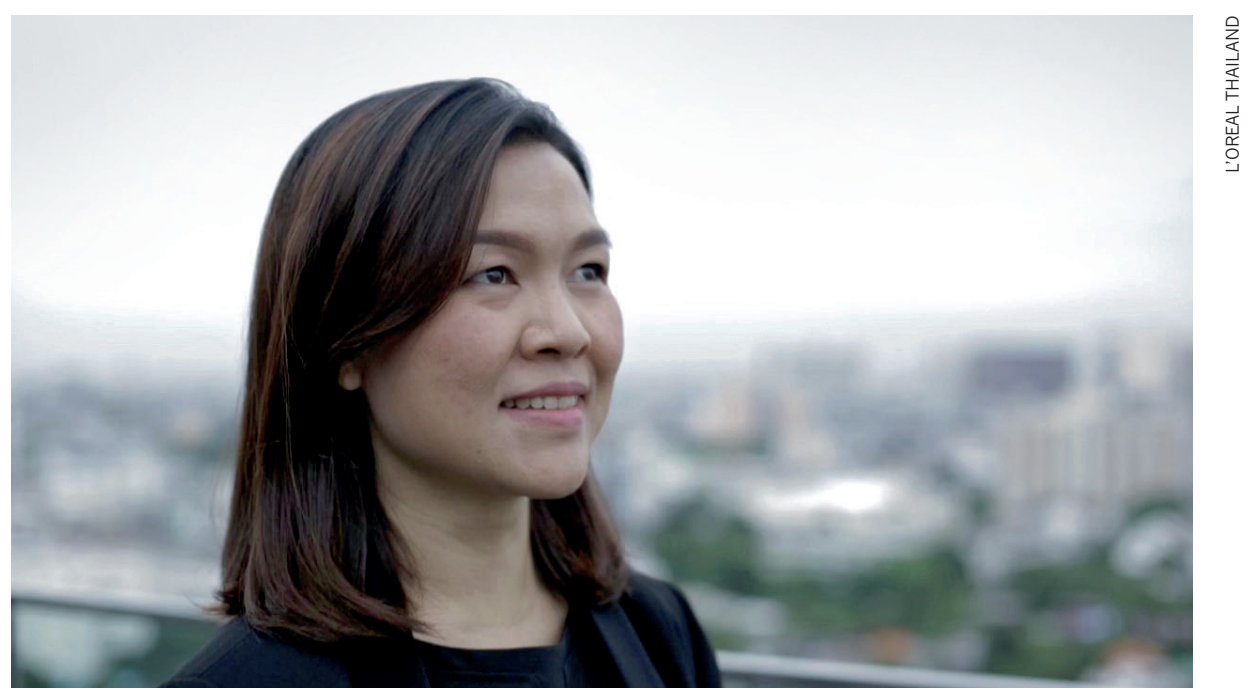

Chanchao Lorthongpanich says a lack of funding can be a problem for biotechnology in Thailand.

Maharjan, her husband and a team of ten other researchers began to lay the foundations of what would become the Research Institute for Bioscience and Biotechnology in Kathmandu.

"It was very, very difficult," she says. "At that time there was no support, no background, nothing." The team all donated money around $\$ 50,000$ in total - to rent some laboratory space and buy some basic equipment so that they could start work.

Since 2011, the institute has grown to 17 staff members and more than 50 students. Its research objectives involve making the most of Nepal's natural resources - in particular, high-altitude microorganisms, which are relatively unexplored and which, because of their extreme environment, could harbour biological compounds that are not found in organisms that live at lower altitudes.

The results so far are promising: "We have isolated anticancer drugs and they are highly potent against kidney, liver and lung cancer."

Maharjan herself has been based at Harvard University in Cambridge, Massachusetts, since 2016 as a research fellow, studying emerging technologies such as $3 \mathrm{D}$ printing of tissues and organs-on-a-chip. "I came to learn these technologies and we are going to apply them to our lab in Nepal," she says.

The Kathmandu institute has received support from funding agencies around the globe, such as the World Academy of Sciences, the Elsevier Foundation and the Alexander von Humboldt Foundation - but not from the Nepalese government, because there are few national funding agencies, and none dedicated to basic science.

Maharjan is encouraged by the fact that many Nepalese scientists who had previously left are now returning with newfound expertise and experience. She encourages younger Nepalese people to consider a biotechnology career.

"If you are passionate about science and want to improve the quality of people's lives through research, then biotechnology can be a very rewarding career for you."

\section{Principal investigator at the Siriraj Center of Excellence for Stem Cell Research in Bangkok, Thailand.}

Stem-cell research is one of the hottest areas of biomedical science at the moment and, as a researcher at the Siriraj Center of Excellence for Stem Cell Research in Bangkok, Chanchao Lorthongpanich is in the thick of it. Her interest was first piqued as a graduate student, when she earned her master's degree studying the cloning of cattle, and of domestic and wild cats.

Her work now focuses on generating human platelets in the laboratory. She is using bone-marrow stem cells and induced pluripotent stem cells - adult cells that have been reverted to a stem-cell state - to generate megakaryocytes, the bone-marrow cells that produce platelets. "Platelet deficiency is life-threatening [but] the shortage of donated platelets is quite common in Thailand," Lorthongpanich says. Currently, getting enough platelets for one person requires blood donations from four to six donors from the same blood group, and there is a risk that the patient will develop an immune response against the donated cells.

Lorthongpanich hopes that growing platelets in a laboratory from stem cells will reduce the risk of contamination associated with donor platelets, and allow genetic engineering of the platelets to make them universally acceptable, regardless of blood group.

The challenge is getting the stem-cellderived bone marrow to produce enough platelets; it makes much less in the lab than its

\section{CHANCHAO LORTHONGPANICH Make the most of your resources}


counterpart does in vivo, partly because of the difficulty of keeping the bone-marrow cells alive and healthy in vitro.

Lorthongpanich says a lack of funding can be a problem for biotechnology research in Thailand. "It must be accepted that biotechnology research is an expensive type of research; cells need to be fed with new culture media every day, and that costs money," she says. Government funding is available, but Lorthongpanich says it's not enough. It can also be difficult to source laboratory equipment and materials. But Thailand's low cost of living could make it attractive for business, she says.

"It makes Thailand a good place for those that would like to set up biotechnology factories for large-scale production of biomedical products." The Thai government has highlighted biotechnology as one of ten industries it is keen to encourage overseas collaboration in, and it has offered special visas for scientists, investors and entrepreneurs in the field. Lorthongpanich points to the Thailand Center of Excellence for Life Sciences, which facilitates cooperation among domestic and international organizations in the industry.

Her advice for aspiring Thai biotechnologists is to be realistic with what they can achieve, while maintaining their ambition. "Accepting your own limitations does not mean giving up, but rather focusing your efforts and making the best use of the available resources."

\section{KHATIJAH YUSOFE You can work anywhere}

\section{Professor at the department of \\ Microbiology, University Putra \\ Malaysia in Serdang, Malaysia.}

Khatijah Yusoff was working in virology when she learnt that one particular virus which causes Newcastle disease, a respiratory, gastrointestinal and neurological condition in birds - had shown anticancer activity. "This virus: apparently it kills human cancer cells, but it does not do any harm to us," she says. She knew that some clinical trials of Newcastle virus-based

\section{"You don't have to look at the market in Malaysia alone - you can work anywhere."} anticancer treatments were already under way in the United States, but Yusoff started her own research programme on the virus in Malaysia, using an endemic and highly virulent local strain.

The work is only at the preclinical stage, but Yusoff is already aware of a catch when

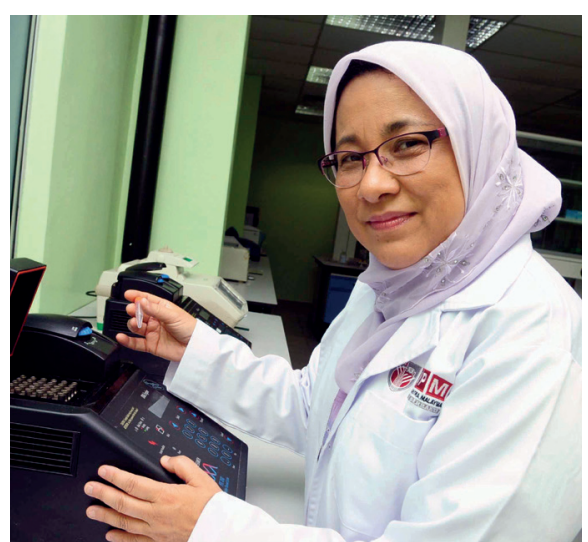

Khatijah Yusoff.

working with such a virus. "We have a huge poultry industry in Malaysia, so I can't imagine the patients coming out and shedding the virus to the poultry because then I'd be behind bars."

That is not the only challenge. Although Malaysia has a number of advantages for clinical research - such as a large, ethnically diverse population base for clinical trials - many of the materials needed for scientific research have to be sourced beyond its borders, and can take months to arrive. And although Malaysia is rich in biotechnology talent, Yusoff says that many graduates are struggling to find jobs in the country.

Yusoff's advice to graduates is to think internationally. "You don't have to look at the market in Malaysia alone - you can work anywhere around the world," she says. "But you have to be good, you have to have the passion, you have to be very industrious and read a lot and really work hard."

\section{JENNY LESLIE Build it and they will come}

\section{Chief operating officer and co-founder of BioTech Africa in Cape Town, South Africa.}

Jenny Leslie's career path has been eventful by most standards. Raised in South Africa, she did her undergraduate and postgraduate scientific studies in Glasgow, UK, dipped into information technology for a while, worked in enterprise project management, co-ran a small radio-technology sales business and set up a Brazilian ju-jitsu academy.

"I always had this niggling feeling that I should get back into science," she says. The opportunity came when she was approached to help set up a biotech company to commercialize work in generating recombinant proteins for HIV diagnosis kits.

After spending two years refining the business plan and raising investment funding - a process Leslie calls "kissing a gazillion frogs" - BioTech Africa was launched in 2014.

The initial idea has expanded beyond HIV, says Leslie: "We were able to make basically any protein we wanted using the same intellectual property." The company now manufactures recombinant antigens for diseases including tuberculosis, typhoid, dengue and Zika, and has customers all around the world.

Setting up a fully equipped laboratory in Cape Town meant bringing in all of the equipment from overseas, which Leslie estimates added around $20 \%$ to the set-up costs compared with what might be paid by companies in the West. However, salaries and rents in South Africa are substantially lower: Leslie says they save $70 \%$ on overhead costs compared with a similar operation in somewhere like the United States.

Although the biotechnology industry in South Africa is relatively small, there is momentum for growth. "There's a big drive for products made in Africa by Africans, so it bodes well for the future." Her company is the only manufacturer of recombinant proteins in bacteria in Africa, and now Leslie is considering developing a rapid diagnostic test for HIV. "We can make a very competitive HIV test that is all African, and hopefully that will be a very valuable product throughout the continent."

Leslie's advice for others? "If you've got a viable idea and you're persistent enough — and you have to kiss a lot of frogs - it does come right in the end," she says. "I'm a firm believer of 'build it, they will come', as long as you can stick it out." =

Bianca Nogrady is a science journalist and author in New South Wales, Australia.

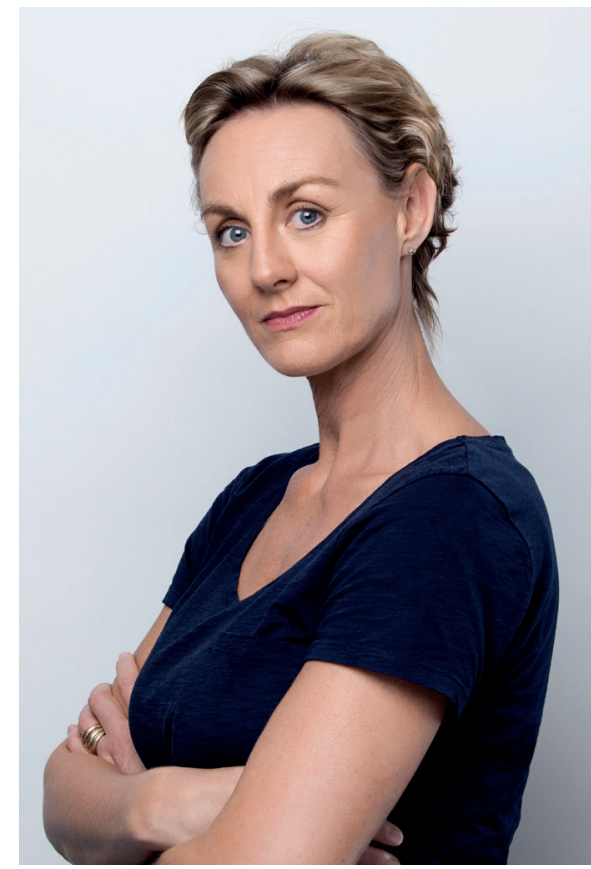

Jenny Leslie. 